\title{
Renewable energy consumption and unemployment: Evidence from a sample of 80 countries and nonlinear estimates
}

\author{
Nicholas Apergis ${ }^{1}$ and Ruhul Salim ${ }^{* 2}$ \\ ${ }^{1}$ Northumbria Business School \\ University of Northumbria \\ Newcastle upon Tyne \\ Tyne and Wear NE1 8ST, United Kingdom \\ e-mail: nicholas.apergis@ @orthumbria.ac.uk \\ and \\ ${ }^{2}$ School of Economics \& Finance \\ Curtin Business School \\ Curtin University, WA 6845 \\ Australia
}

The authors need to express their profound gratitude to two referees who provided comments and suggestions that enhanced the merit of this paper. Needless to say, the usual disclaimer applies.

*Corresponding author: A/Professor of Economics, School of Economics \& Finance, Curtin Business School, Curtin University, Perth, WA 6845. Phone: +61 89266 4577, Fax: +61 89266 3026, E-mail: Ruhul.Salim@cbs.curtin.edu.au 


\title{
Renewable energy consumption and unemployment: Evidence from a sample of 80 countries and nonlinear estimates
}

\begin{abstract}
This paper contributes to the discussion on the dynamic nexus of renewable energy consumption and unemployment by incorporating non-linear cointegration and causality analysis. Using a sample of 80 countries spanning the period 1990-2013 and the advanced generation of unit root, cointegration and non-linear Granger causality methodological approaches in panel data, we obtain mixed results about the impact of renewable energy consumption on unemployment. Although the total findings document a positive impact of renewable energy consumption on unemployment, disaggregated data across specific regions, such as Asia and Latin America, highlight the favourable effect on unemployment, implying that the effect of renewable energy consumption on jobs creation depends on the cost of adopting renewable energy technologies and energy efficiencies that seem to vary across the regions under investigation.
\end{abstract}

Keywords: renewable energy consumption; unemployment; panel data; nonlinearity

JEL Classification: Q20; E24; C33 


\section{Renewable energy consumption and unemployment: Evidence from a sample of 80 countries and nonlinear estimates}

\section{Introduction}

Extensive studies have been conducted on the dynamic relationship between energy consumption and economic growth and more recently on the association between renewable energy consumption and economic growth across a number of economic regions or countries over the past decade (Masih and Masih, 1998; Salim, et al., 2008 Tugcu et al., 2012; Salim et al., 2014; among others). Based on these empirical facts as well as on Okun's law, we can argue that energy consumption, particularly renewable energy consumption, in an economy may affect the rate of unemployment, which is an significant leading indicator about the current and future path of economic growth. The link between renewable energy consumption and unemployment can be explained in terms of the following primary mechanisms: (i) high investment levels and large capacities installed directly exert a positive effect on the employment in the respective industries; (ii) the import effect, according to which, money saved on imports of fossil fuels which are replaced by energy from renewable sources; (ii) counterbalancing the positive effects are reduced investment plans in fossil fuel systems and potential foregone investments and consumption from lower available public and private budgets due to additional costs of renewable energy sources. The balance of these effects compared across different development paths leads to the net economic effects, among which, the net employment effects receives a special attention in this paper.

An additional mechanism that could potentially explain the association between renewable energy and unemployment is related to the level of uncertainty around the exact impacts that generation costs of renewable energy are expected to incur for the level of employment. In particular, renewable energy technologies may require support schemes to overcome high upfront costs, i.e. resources that are not spent elsewhere in the economy and that will also translate into higher costs paid by consumers (Gülen, 2010). Once the capital costs for renewable energy are fully depreciated, generation costs are close to zero and prices for fuel-free technologies of power should consequently fall. The assumptions made around such pricing effects will affect the estimated employment impacts. 
Given the above linkages between the renewable energy consumption and unemployment, it can be argued that the expansion of renewable energy consumption reduces the level of unemployment during periods of economic prosperity. The opposite occurs where there is economic downturn. However, there is hardly any evidence on the dynamic relationship between renewable energy consumption and unemployment or employment. Since this type of dynamic relationship is of great interest to economists as well as to policy makers, this paper attempts to void the research gap. Thus, the primary goal of this study is to analyse the dynamic relationship between renewable energy consumption and unemployment across 80 countries spanning the period of 1990-2013.

Previous studies on the dynamic relationship between energy consumption and economic growth examine four testable hypotheses: growth, conservation, feedback and neutrality. Most of these studies investigate these hypotheses by using aggregate energy consumption and economic growth. However, there are few exceptions such as Apergis and Payne (2012) and Salim, et al (2014) who investigate these causal linkages using renewable and non-renewable energy consumption and economic growth. There is only one study conducted by Payne (2009), who examines the direction of causality between energy consumption and employment using time series data over the period 1976-2006 in Illinois in the US, and finds unidirectional causality from energy consumption to employment which supports the growth hypothesis. However, the author cautions the heavy reliance on non-renewable energy consumption and emphasizes the alternative renewable energy sources as well as improved energy efficiency for future economic growth. Although this study bears significance as the earlier study on the dynamic nexus between energy consumption and employment, however, it suffers from the following limitations. First, it uses only time series data from just one state of the US without covering the whole country. Second, the author uses Toda-Yamamoto (1995) causality analysis, which ensures the asymptotic distribution of the VAR (vector auto-regression) system regardless of the order of integration of variables in question. However, when some standard assumptions concerning the distribution of the error term the Toda- Yamamoto approach is likely to fail. Hence, the empirical findings may be unreliable and thereby policy implications are likely to be misleading. 
This paper contributes to the literature on the dynamic nexus between renewable energy consumption and unemployment by using panel data non-linear estimates. We conduct unit root test by allowing structural breaks in the data by following the $\operatorname{LM}(\lambda)$ test of Carrion-i-Silvestre et al. (2005) and examine the possibility of cross-sectional dependence by following the second generation unit root test of Pesaran (2004). We further apply the Westerlund (2006) procedures for cointegration allowing for multiple breaks in the data and estimate the long-run cointegration vector using the fully modified ordinary least squares (FMOLS). Finally, we extend the analysis by estimating a nonlinear panel smooth transition vector error correction model (VECM) to take into account nonlinear dynamic relationship between the variables in the longrun by following Gonzalez et al. (2005) and Omay and Kan (2010).

The reminder of the article proceeds as follows. Section 2 outlines the data sources and variables followed by methodologies and analysis of empirical results in Section 3. Finally, conclusion and policy implications are given in Section 4.

\section{Variables and Data Sources}

Annual data from 1990 to 2013 were obtained for 80 countries listed in the Appendix. Data on unemployment rates (U), renewable energy consumption (RE) defined in millions of kilowatt hours, capital stock (K) in billions of constant 2000 U.S. dollars, the real exchange rate $(\mathrm{E})$ defined as the effective exchange rate with respect to the country's major trading partners, the amount of provided credit (CREDIT) to the economy from the monetary and banking sector, and, finally, government expenditures (G) in billions of constant 2000 U.S. dollars, are used. All data, except those in renewable energy consumption, were obtained from Datastream, while those in renewable energy consumption were obtained from the iOECDlibrary, available through the Curtin University Library system.

\section{Methodology and Analysis of Results}

This section presents the empirical model that investigates the long-run impact of renewable energy consumption on unemployment. The long-run (linear) equation framework yields:

$$
U_{i t}=\alpha_{i}+\alpha_{1 i} R E_{i t}+\alpha_{2 i} K_{i t}+\alpha_{3 i} E_{i t}+\alpha_{4 i} \operatorname{CREDIT}_{i t}+\alpha_{5 i} G_{i t}+\varepsilon_{i t}
$$


where $i=1, \ldots, N$ for each country in the panel, $t=1, \ldots, T$ refers to the time period, $\mathrm{U}$ is the unemployment rate, $\mathrm{RE}$ denotes renewable energy consumption, $\mathrm{K}$ is the capital stock, E denotes the real exchange rate, CREDIT is the amount of credit provided to the real economy, and $\mathrm{G}$ highlights government expenditures. The parameter $\alpha_{\mathrm{i}}$ allows for the possibility of country-specific fixed effects. Equation (1) is estimated for 80 countries as well as for a number of different regions, namely European Union, Western Europe, Asia, Latin America, and Africa. The list of countries is given in Appendix 1.

\section{Panel unit root tests}

We assess renewable energy and unemployment dynamics across each subgroup using panel data unit root tests. To overcome the well-known problem of crosssectional independence hypothesis among panel members, we apply secondgeneration panel unit root tests that relax this restrictive assumption required by firstgeneration tests. Second-generation tests are those of Smith et al. (2004) and Pesaran (2007) allowing for a variety of dependence across the different units.

One way of testing for the presence of cross-section dependence in the data is to carry out the test of Pesaran (2004) and to compute the Cross section Dependence (CD) statistic. The test of Pesaran (2004) is based on a simple average of all pair-wise correlation coefficients of the OLS residuals obtained from standard augmented Dickey-Fuller (1979) regressions for each individual in the panel. Under its null hypothesis of cross-sectional independence, the test follows asymptotically a twotailed standard normal distribution. The results reported in Table 1 provide evidence in favor of the presence of cross-sectional dependence in the data since for all series the CD statistics are always highly significant irrespective of the number of lags (from 1 to 3 ) included in the ADF regressions. In other words, we reject the null hypothesis of cross-section independence. The first 2 nd generation unit root test that we use is the test by Pesaran (2007) who suggests a simple way of accounting for crosssectional dependence that does not require the estimation of factor loading. His method is based on augmenting the usual ADF regression with the lagged crosssectional mean and its first difference to capture the cross-sectional dependence that arises through a single-factor model. The resulting individual ADF test statistics (CADF) or the rejection probabilities can then be used to develop modified versions of the t-bar test proposed by Im et al. (2003), such as the Cross-sectionally augmented 
IPS (CIPS) or a truncated version of the CIPS statistic (CIPS*), or the inverse normal test (or the $\mathrm{Z}$ test) suggested by Choi (2001) that combines the p-values of the individual tests (CZ). Critical values reported in Pesaran (2007) are provided through Monte Carlo simulations for a specific specification of the deterministic component and depend both on the cross-sectional and time series dimensions. The null hypothesis of all tests is the unit root.

The second set of unit root tests of the 2 nd generation are the bootstrap tests of Smith et al. (2004), which use a sieve sampling scheme to account for both the time series and cross-sectional dependencies of the data through bootstrap blocks. The specific tests that we consider are denoted t, LM, max, and min. $t$ is the bootstrap version of the well-known panel unit root test of Im et al. (2003), LM is a mean of the individual Lagrange Multiplier (LMi) test statistics, originally introduced by Solo (1984), max is the test of Leybourne (1995), and min is a (more powerful) variant of the individual Lagrange Multiplier (LMi). All four tests are constructed with a unit root under the null hypothesis and heterogeneous autoregressive roots under the alternative, which indicates that a rejection should be taken as evidence in favor of stationarity for at least one country.

Both unit root test results are presented in Table 2. The results document evidence of stationary series only when the variables under investigation are first differenced. The results remain robust across all regions under consideration. Therefore, we conclude that unemployment, renewable energy consumption and the capital stock are non-stationary and integrated of order one at the three significance levels. 
Table 1: Cross-section correlations of the errors in the ADF(p) regressions (CD tests, p-values inside brackets)

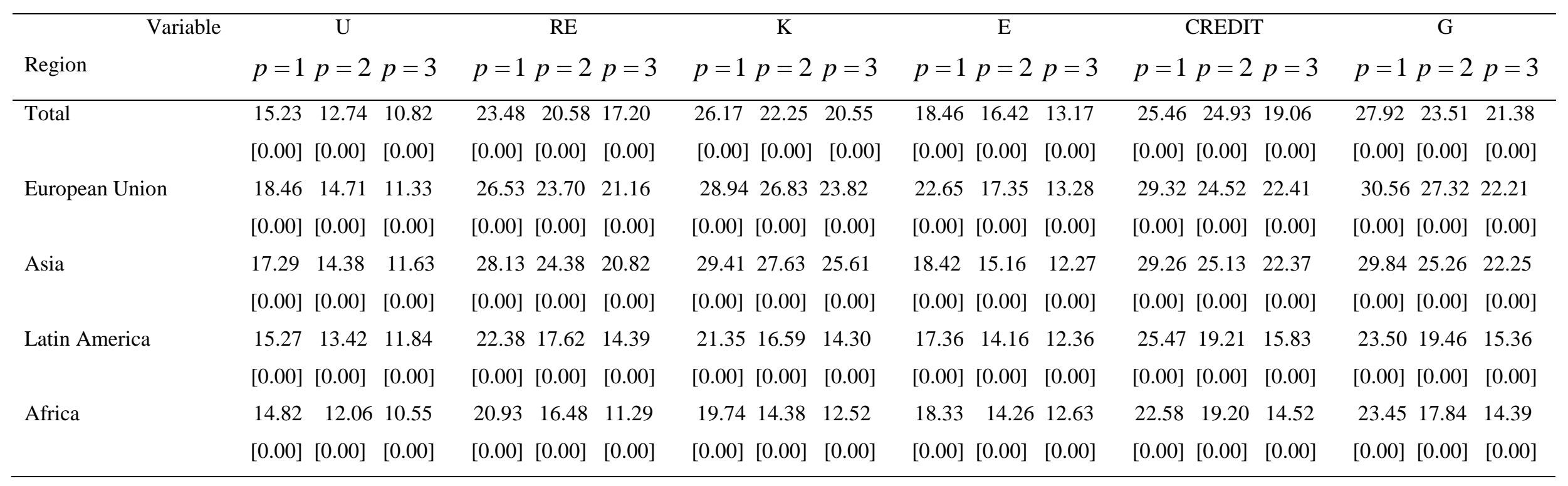

Notes: Under the null of cross-sectional independence the CD statistic is distributed as a two-tailed standard normal. Results based on the test by Pesaran (2004). 
Table 2: Panel unit roots, Peseran Test (without breaks)

\section{(CIPS statistics, CIPS* statistics in brackets)}

\begin{tabular}{|c|c|c|c|c|c|c|c|c|c|c|c|c|c|c|c|c|c|c|}
\hline \multirow{3}{*}{$\begin{array}{l}\text { Region } \\
\text { Total }\end{array}$} & \multirow{2}{*}{\multicolumn{3}{|c|}{$p=1 p=2 p=3$}} & \multirow{2}{*}{\multicolumn{3}{|c|}{$p=1 p=2 p=3$}} & \multirow{2}{*}{\multicolumn{3}{|c|}{$\begin{array}{c}\mathrm{K} \\
p=1 p=2 p=3\end{array}$}} & \multirow{2}{*}{\multicolumn{3}{|c|}{$p=1 p=2 p=3$}} & \multirow{2}{*}{\multicolumn{3}{|c|}{$\begin{array}{c}\text { CREDIT } \\
p=1 p=2 p=3\end{array}$}} & \multicolumn{3}{|c|}{$\mathrm{G}$} \\
\hline & & & & & & & & & & & & & & & & $p=1$ & $p=2$ & $p=3$ \\
\hline & -1.93 & -1.71 & -1.64 & -1.42 & -1.28 & -1.14 & -1.10 & -1.02 & -0.84 & -1.84 & -1.75 & -1.52 & -1.48 & -1.23 & -1.10 & -1.26 & -1.12 & -0.96 \\
\hline & {$[-1.62$} & -1.41 & $-1.25]$ & {$[-1.36$} & -1.17 & $-1.04]$ & {$[-1.23$} & -1.12 & $-0.96]$ & {$[-1.71$} & -1.45 & $-1.31]$ & {$[-1.39$} & -1.24 & $-1.18]$ & {$[-1.29$} & -1.22 & $-1.06]$ \\
\hline \multirow[t]{2}{*}{ European Union } & -1.16 & -1.11 & -0.93 & -1.34 & -1.20 & -1.02 & -1.24 & -1.13 & -0.89 & -1.22 & -1.15 & -0.98 & -1.30 & -1.15 & -1.05 & -1.34 & -1.25 & -1.19 \\
\hline & {$[-1.14$} & -1.04 & $-0.86]$ & {$[-1.28$} & -1.15 & $-0.98]$ & {$[-1.35$} & -1.22 & $-1.07]$ & {$[-1.18$} & -1.05 & $-0.91]$ & {$[-1.25$} & -1.19 & $-1.08]$ & {$[-1.31$} & -1.16 & $-1.11]$ \\
\hline \multirow[t]{2}{*}{ Asia } & -1.26 & -1.18 & -1.09 & -1.36 & -1.19 & -1.02 & -1.28 & -1.13 & -1.02 & -1.32 & -1.23 & -1.12 & -1.38 & -1.24 & -1.15 & -1.25 & -1.12 & -1.00 \\
\hline & {$[-1.19$} & -1.01 & $-0.83]$ & {$[-1.30$} & -1.23 & $-1.12]$ & {$[-1.36$} & -1.21 & $-1.15]$ & {$[-1.16$} & -1.10 & $-0.95]$ & {$[-1.24$} & -1.14 & $-1.03]$ & {$[-1.22$} & -1.10 & $-0.92]$ \\
\hline \multirow[t]{2}{*}{ Latin America } & -1.26 & -1.15 & -1.03 & -1.18 & -1.12 & -1.04 & -1.31 & -1.19 & -1.11 & -1.29 & -1.18 & -1.05 & -1.23 & -1.10 & -1.01 & -1.28 & -1.14 & -1.01 \\
\hline & {$[-1.16$} & -1.03 & $-0.82]$ & {$[-1.10$} & -1.02 & $-0.89]$ & {$[-1.24$} & -1.10 & $-0.86]$ & {$[-1.18$} & -1.11 & $-0.93]$ & {$[-1.14$} & -1.05 & $-0.90]$ & {$[-1.21$} & -1.12 & $-0.85]$ \\
\hline \multirow[t]{2}{*}{ Africa } & -1.22 & -1.16 & -1.01 & -1.33 & -1.17 & -1.09 & -1.34 & -1.25 & -1.12 & -1.26 & -1.18 & -1.04 & -1.37 & -1.24 & -1.12 & -1.36 & -1.22 & -1.06 \\
\hline & {$[-1.16$} & -1.03 & $-0.82]$ & {$[-1.25$} & -1.13 & $-0.96]$ & {$[-1.27$} & -1.14 & $-1.02]$ & {$[-1.19$} & -1.14 & $-0.96]$ & {$[-1.22$} & -1.10 & $-0.91]$ & {$[-1.25$} & -1.17 & $-1.03]$ \\
\hline
\end{tabular}


(Table 2 continued)

\begin{tabular}{|c|c|c|c|c|c|c|c|c|c|c|c|c|c|c|c|c|c|c|}
\hline \multirow[b]{2}{*}{ Region } & \multicolumn{3}{|c|}{$\Delta \mathrm{U}$} & \multicolumn{3}{|c|}{$\Delta \mathrm{RE}$} & \multicolumn{3}{|c|}{$\Delta \mathrm{K}$} & \multicolumn{3}{|c|}{$\Delta \mathrm{E}$} & \multicolumn{3}{|c|}{$\triangle \mathrm{CREDIT}$} & \multicolumn{3}{|c|}{$\Delta \mathrm{G}$} \\
\hline & $p=1$ & $p=2$ & $p=3$ & $p=1$ & $p=2$ & $p=3$ & $p=1$ & $p=2$ & $p=3$ & $p=1$ & $p=2$ & $p=3$ & $p=1$ & $p=2$ & $p=3$ & $p=1$ & $p=2$ & $p=3$ \\
\hline \multirow[t]{2}{*}{ Total } & -4.35 & -4.18 & -3.46 & -4.25 & -4.81 & -4.49 & -3.85 & -3.26 & -3.15 & -4.39 & -4.21 & -3.83 & -4.41 & -4.25 & -4.09 & -3.98 & -3.52 & -3.24 \\
\hline & {$[-4.27$} & -4.12 & $-3.58]$ & {$[-4.11$} & -4.06 & $-3.58]$ & {$[--3.39$} & -3.20 & $-3.06]$ & {$[-4.30$} & -4.22 & $-3.61]$ & {$[-4.25$} & -4.16 & $-3.82]$ & {$[-3.57$} & -3.41 & $-3.20]$ \\
\hline \multirow[t]{2}{*}{ European Union } & -4.67 & -4.36 & -4.15 & -4.48 & -4.25 & -4.11 & -4.49 & -4.35 & -3.92 & -4.81 & -4.65 & -4.36 & -4.53 & -4.30 & -4.23 & -4.65 & -4.40 & -4.22 \\
\hline & {$[-4.42$} & -4.27 & $-3.64]$ & {$[-4.35$} & -4.13 & $-3.86]$ & {$[-4.45$} & -4.27 & $-3.88]$ & {$[-4.51$} & -4.19 & $-3.85]$ & {$[-4.62$} & -4.24 & $-4.06]$ & {$[-4.58$} & -4.25 & $-3.92]$ \\
\hline \multirow[t]{2}{*}{ Asia } & -5.61 & -4.42 & -4.16 & -5.64 & -4.98 & -4.26 & -4.81 & -4.37 & -4.12 & -5.24 & -4.61 & -4.25 & -5.12 & -4.62 & -4.39 & -4.57 & -4.29 & -4.11 \\
\hline & {$[-4.93$} & -4.52 & $-4.30]$ & {$[-5.01$} & -4.62 & $-4.25]$ & {$[-4.72$} & -4.16 & $-3.79]$ & {$[-4.97$} & -4.38 & $-4.05]$ & {$[-5.14$} & -4.72 & $-4.26]$ & {$[-4.62$} & -4.25 & $-4.02]$ \\
\hline \multirow[t]{2}{*}{ Latin America } & -4.60 & -4.52 & -4.32 & -4.85 & -4.43 & -4.19 & -5.11 & -4.95 & -4.48 & -4.28 & -4.01 & -3.74 & -4.60 & -4.41 & -4.22 & -4.82 & -4.45 & -4.28 \\
\hline & {$[-4.26$} & -4.03 & $-3.65]$ & {$[-5.13$} & -4.61 & $-4.36]$ & {$[-4.48$} & -4.43 & $-4.16]$ & {$[-4.21$} & -3.83 & $-3.48]$ & {$[-4.38$} & -4.11 & $-3.82]$ & {$[-4.56$} & -4.41 & $-4.24]$ \\
\hline \multirow[t]{2}{*}{ Africa } & -5.21 & -4.64 & -4.19 & -5.31 & -4.78 & -4.38 & -5.41 & -4.93 & -4.37 & -4.82 & -4.43 & -4.20 & -5.12 & -4.89 & -4.35 & -5.14 & -4.90 & -4.56 \\
\hline & {$[-4.64$} & -4.31 & $-4.25]$ & {$[-4.58$} & -4.32 & $-3.99]$ & {$[-4.75$} & -4.43 & $-4.22]$ & {$[-4.61$} & -4.35 & $-4.12]$ & {$[-4.72$} & -4.48 & $-3.19]$ & {$[-4.89$} & -4.57 & $-4.14]$ \\
\hline
\end{tabular}

Notes: For the Pesaran test=CIPS - Cross-section augmented Im-Pesaran-Shin test. CIPS* - truncated CIPS test. A constant is included in the estimations. $\Delta$ indicates first differences. Rejection of the null hypothesis indicates stationarity at least in one country. Critical values are, respectively, of -2.40 at $1 \%$, -2.22 at $5 \%$, and -2.14 at $10 \%$. $*$ denotes rejection of the null at the $10 \%$ significance level. For the Smith et al. test=Model includes both a constant and a time trend. Rejection of the null hypothesis indicates stationarity at least in one country. Figures indicate p-values. All tests are based on 5,000 bootstrap replications to compute the p-values. The null hypothesis is that of a unit root. 
In further examination of the robustness of the standard panel unit root test results, we employ two panel unit root tests which allow for endogenously determined structural breaks: the $\Gamma_{\mathrm{LM}}{ }^{\mathrm{B}}(\mathrm{p})$ test of Im et al. (2005) and the $\operatorname{LM}(\lambda)$ test of Carrion-i-Silvestre et al. (2005). The Im et al. (2005) test allows for a single break, whereas the Carrion-iSilvestre et al. (2005) test allows for an unknown number of breaks in the level of each series. The null hypothesis for the Im et al. (2005) test is nonstationarity while the null hypothesis for the Carrion-i-Silvestre et al. (2005) test is stationarity. ${ }^{1}$ Table 3 shows that the Im et al. (2005) test fails to reject the null hypothesis of nonstationarity in levels; however, with the variables in first-differences, the null hypothesis of non-stationarity is rejected at the $1 \%$ significance level. The Carrion-iSilvestre et al. (2005) test rejects the null hypothesis of stationarity in levels at the $1 \%$ significance level; however, with the variables in first-differences, it fails to reject the null hypothesis of stationarity. Therefore, the results indicate that the respective variables are integrated of order one, with the structural break not to follow a uniform pattern and to be associated with particular events across the areas under consideration.

Turning to the location of the breakpoints, the breakpoint around 2008 coincides (where appropriate) with the recent financial crisis, the breakpoint around 1997 coincides (where appropriate) with the Asian crisis event which resulted in episodes of increased unemployment, while the breakpoints around 2001 and 2009 coincide with the European Union (EU) formation event and the recent European sovereign debt crisis. The breakpoint around 1993 coincides with oil price spikes which resulted in short episodes of increased $R \& D$ expenditure on renewable energy in OECD countries (Gan and Smith, 2011). The 1999 and 2006 turning points for the case of renewable energy consumption across the Latin America countries coincide with the enactment of laws and programs that established projects related to various forms of renewable energy promotions and a set of tax benefits targeted to provide a boost to energy consumption coming from renewable sources. With respect to the

\footnotetext{
${ }^{1}$ Both statistics are normally distributed under the null hypothesis. The direction of the divergence under the alternative hypothesis determines whether we should use the right or left tail of the normal distribution to reject the null hypothesis. The $\Gamma_{\mathrm{LM}}{ }^{\mathrm{B}}(\mathrm{p})$ statistic of Im et al. (2005) diverges to negative infinity and is compared to the left tail, whereas the $\operatorname{LM}(\lambda)$ statistic of Carrion-i-Silvestre et al. (2005) diverges to positive infinity, and thus compared to the right tail. The maximum number of common factors and structural breaks in the Carrion-i-Silvestre et al. (2005) test are set equal to five, which is common in the literature.
} 
remaining variables in the Latin American case, the break point around 2002 coincides with the presence of the beginning of large commodity trade shocks that the exporting Latin American countries suffered in the early 2002 and signaled their exposure to deep recessionary phases. In terms of the breakpoint 2002 concerning the renewable energy variables for the case of the African countries, it coincides with the agenda of the Johannesburg World Summit on Sustainable Development (WSSD) in 2002. In the UN-led implementation plan of action for the WSSD, dubbed WEHAB (which stands for Water, Energy, Health, Agriculture and Biodiversity), top priority was given to the renewables and other alternative forms of energy services (WEHAB Working Group, 2002). One of the targets proposed at WSSD was for every country to commit itself to meeting $10 \%$ of its national energy supply from renewables. Although the $10 \%$ target was not agreed to at the summit, there was general consensus that African countries should commit themselves to promotion of renewables. Finally, the breakpoint 2007 for the case of the African countries coincides with food price shocks that affected negatively the majority of the countries under study.

Table 3: Panel unit root tests with breaks

\begin{tabular}{|c|c|c|c|}
\hline Variables & $\begin{array}{c}\text { Im et al. } \\
(\Gamma \operatorname{LMB}(p))\end{array}$ & $\begin{array}{c}\text { Carrion-i-Silvestre } \\
\text { et al. }(\operatorname{LM}(\lambda))\end{array}$ & Break Location \\
\hline \multicolumn{4}{|l|}{ Total } \\
\hline $\mathrm{U}$ & -2.46 & $29.75^{*}$ & $1993 ; 1997 ; 2001 ; 2008$ \\
\hline$\Delta \mathrm{U}$ & $-35.38^{*}$ & 1.37 & \\
\hline $\mathrm{RE}$ & -2.24 & $39.78^{*}$ & 1993; 1997 \\
\hline$\Delta \mathrm{RE}$ & $-46.49^{*}$ & 1.32 & \\
\hline $\mathrm{K}$ & -2.28 & $30.94^{*}$ & $1993 ; 1997 ; 2001 ; 2008$ \\
\hline$\Delta \mathrm{K}$ & $-31.25^{*}$ & 1.36 & \\
\hline $\mathrm{E}$ & -2.35 & $34.59^{*}$ & $1993 ; 1997 ; 2001 ; 2008$ \\
\hline$\Delta \mathrm{E}$ & $-36.71^{*}$ & 1.24 & \\
\hline CREDIT & -2.17 & $38.92^{*}$ & $1993 ; 1997 ; 2001 ; 2008$ \\
\hline$\triangle \mathrm{CREDIT}$ & $-35.62^{*}$ & 1.27 & \\
\hline $\mathrm{G}$ & -1.69 & $39.83^{*}$ & $1993 ; 1997 ; 2001 ; 2008$ \\
\hline$\Delta \mathrm{G}$ & $-42.56^{*}$ & 1.13 & \\
\hline \multicolumn{4}{|c|}{ European Union } \\
\hline $\mathrm{U}$ & -2.68 & $31.49^{*}$ & 2001; 2009 \\
\hline$\Delta \mathrm{U}$ & $-37.93^{*}$ & 1.28 & \\
\hline $\mathrm{RE}$ & -2.48 & $46.92^{*}$ & $1993 ; 2001$ \\
\hline$\Delta \mathrm{RE}$ & $-47.63^{*}$ & 1.43 & \\
\hline $\mathrm{K}$ & -2.33 & $34.61^{*}$ & $2001 ; 2009$ \\
\hline$\Delta \mathrm{K}$ & $-35.58^{*}$ & 1.45 & \\
\hline $\mathrm{E}$ & -2.07 & $39.25^{*}$ & $2001 ; 2009$ \\
\hline$\Delta \mathrm{E}$ & $-38.84^{*}$ & 1.32 & \\
\hline
\end{tabular}




\begin{tabular}{|c|c|c|c|}
\hline CREDIT & -2.39 & $38.79^{*}$ & $2001 ; 2009$ \\
\hline$\triangle$ CREDIT & $-45.62^{*}$ & 1.38 & \\
\hline G & -2.17 & $38.59^{*}$ & $2001 ; 2009$ \\
\hline$\Delta \mathrm{G}$ & $-46.72^{*}$ & 1.39 & \\
\hline \multicolumn{4}{|l|}{ Asia } \\
\hline $\mathrm{U}$ & -2.19 & $38.52^{*}$ & $1997 ; 2008$ \\
\hline$\Delta \mathrm{U}$ & $-44.92^{*}$ & 1.24 & \\
\hline $\mathrm{RE}$ & -2.17 & $43.29^{*}$ & $1997 ; 2008$ \\
\hline$\Delta \mathrm{RE}$ & $-49.50^{*}$ & 1.27 & \\
\hline K & -2.16 & $36.47^{*}$ & $1997 ; 2008$ \\
\hline$\Delta \mathrm{K}$ & $-38.48^{*}$ & 1.31 & \\
\hline $\mathrm{E}$ & -2.48 & $33.76^{*}$ & $1997 ; 2008$ \\
\hline$\Delta \mathrm{E}$ & $-34.27^{*}$ & 1.46 & \\
\hline CREDIT & -2.40 & $33.75^{*}$ & $1997 ; 2008$ \\
\hline$\triangle$ CREDIT & $-37.36^{*}$ & 1.52 & \\
\hline G & -1.95 & $46.78^{*}$ & $1997 ; 2008$ \\
\hline$\Delta \mathrm{G}$ & $-53.41^{*}$ & 1.02 & \\
\hline \multicolumn{4}{|c|}{ Latin America } \\
\hline $\mathrm{U}$ & -2.58 & $24.56^{*}$ & $2002 ; 2008$ \\
\hline$\Delta \mathrm{U}$ & $-26.72^{*}$ & 1.51 & \\
\hline $\mathrm{RE}$ & -2.18 & $35.42^{*}$ & 1999; 2006 \\
\hline$\Delta \mathrm{RE}$ & $-38.32^{*}$ & 1.37 & \\
\hline $\mathrm{K}$ & -2.16 & $36.47^{*}$ & $1997 ; 2008$ \\
\hline$\Delta \mathrm{K}$ & $-38.48^{*}$ & 1.31 & \\
\hline E & -2.50 & $28.46^{*}$ & $1997 ; 2008$ \\
\hline$\Delta \mathrm{E}$ & $-31.84^{*}$ & 1.46 & \\
\hline CREDIT & -2.46 & $34.75^{*}$ & $1997 ; 2008$ \\
\hline$\triangle \mathrm{CREDIT}$ & $-31.06^{*}$ & 1.56 & \\
\hline G & -2.82 & $31.74^{*}$ & $1997 ; 2008$ \\
\hline$\Delta \mathrm{G}$ & $-32.53^{*}$ & 1.65 & \\
\hline \multicolumn{4}{|l|}{ Africa } \\
\hline $\mathrm{U}$ & -2.34 & $31.16^{*}$ & 2007 \\
\hline$\Delta \mathrm{U}$ & $-35.60^{*}$ & 1.48 & \\
\hline $\mathrm{RE}$ & -2.37 & $34.41^{*}$ & 2002 \\
\hline$\Delta \mathrm{RE}$ & $-37.82^{*}$ & 1.53 & \\
\hline $\mathrm{K}$ & -2.59 & $31.20^{*}$ & 2007 \\
\hline$\Delta \mathrm{K}$ & $-32.52^{*}$ & 1.63 & \\
\hline E & -2.41 & $37.08^{*}$ & 2007 \\
\hline$\Delta \mathrm{E}$ & $-36.54^{*}$ & 1.58 & \\
\hline CREDIT & -2.14 & $36.72^{*}$ & 2007 \\
\hline$\Delta$ CREDIT & $-39.88^{*}$ & 1.25 & \\
\hline $\mathrm{G}$ & -2.28 & $43.31^{*}$ & 2007 \\
\hline$\Delta \mathrm{G}$ & $-38.24^{*}$ & 1.37 & \\
\hline
\end{tabular}

Notes: The null of the $\Gamma_{\mathrm{LM}}{ }^{\mathrm{B}}(\mathrm{p})$ test implies non-stationarity, while that of the $\operatorname{LM}(\lambda)$ test implies stationarity. For both tests we use a trimming parameter of $0.1 \mathrm{~T}$. The number of structural breaks for the latter test is up to 5. The tests are computed using the Bartlett kernel. All bandwidths and lag lengths are chosen according to $4(\mathrm{~T} / 100)^{2 / 9}$. The critical value for the $\Gamma_{\mathrm{LM}}{ }^{\mathrm{B}}(\mathrm{p})$ test at the $1 \%$ significance level is -5.127 , while the critical value for the $\operatorname{LM}(\lambda)$ test at the $1 \%$ significance level is 18.631.* denotes statistical significance at $1 \%$.

Nonlinear panel cointegration 
Given the respective variables are integrated of order one; we examine panel cointegration with consideration for possible structural breaks following Westerlund (2006). The equation to be estimated is specified as follows within a break-augmented panel regression framework:

$$
U_{i t}=\psi_{i j}+\delta_{1 i} R E_{i t}+\delta_{2 i} K_{i t}+\delta_{3 i} E_{i t}+\delta_{4 i} C R E D I T_{i t}+\delta_{5 i} G_{i t}+\varepsilon_{i t}
$$

Where $\delta_{1 i}, \delta_{2 i}, \delta_{3 i}, \delta_{4 i}$, and $\delta_{5 i}$ are country-specific slopes that are assumed to be constant over time, while $\psi_{i j}\left(\mathrm{j}=1, \ldots, \mathrm{m}_{\mathrm{i}}+1\right)$ is a country-specific intercept that is subject to $\mathrm{m}_{\mathrm{i}}$ structural breaks. We expect that an increase in renewable energy will lead to a decrease in the unemployment rate $\left(\delta_{1 \mathrm{i}}<0\right)$ Given the presence of the control variables, their impact on unemployment will be as follows: increases in the stock of capital will likely decrease the unemployment rate, $\left(\delta_{2 \mathrm{i}}>0\right)$. Next, increases in the effective exchange rate are considered as an indication of the domestic currency depreciation and, therefore, are expected to lead to unemployment reduction, $\left(\delta_{3 \mathrm{i}}<0\right)$. Increases in both the amount of credit flowing into the economy and government expenditures are expected to contribute to lower levels of unemployment $\left(\delta_{4 \mathrm{i}}<0\right.$, $\left.\delta_{5 i}<0\right)$.

Standard panel cointegration tests can be used with respect to equation (2) in the absence of structural breaks. However, if there are structural breaks, then this testing procedure is no longer valid since the relationship in equation (2) is no longer linear in $\psi_{i j}$. This poses a serious problem as most cointegration tests cannot be used to discriminate between cointegration with structural shifts and the absence of cointegration. For the estimation of the number of structural breaks and their locations, Westerlund (2006) suggests using the least squares approach by Bai and Perron (2003) which is based on solving the following minimization problem:

$$
\left(\tau_{i 1}, \cdots, \tau_{\min }\right)=\underset{\tau_{i 1, \ldots}, \ldots}{\arg \min } \sum_{j=1}^{m_{i}+1} \sum_{t=\tau_{i j-1}+1}^{\tau_{i j}} \varepsilon_{i t}^{2}
$$

Where $\varepsilon_{\mathrm{it}}$ is the estimated regression error from equation (2) based on the partition $\tau_{\mathrm{ij}}$ with $\mathrm{j}=1, \ldots, \mathrm{m}_{\mathrm{i}}$ and a trimming parameter of $\tau_{\min }$ which imposes a minimum length for each subsample such that $\tau_{\mathrm{ij} j}-\tau_{\mathrm{ij}-1}>\tau_{\min }$. The estimation is performed in two steps: (1) the minimum of the sum of squared residuals is estimated with the associated structural breaks, $\tau_{\mathrm{ij}}$, for each possible break number $\mathrm{m}_{\mathrm{i}}=1, \ldots, \mathrm{m}_{\max }$ where $\mathrm{m}_{\max }<\mathrm{m}_{\mathrm{i}}$ 
is a predetermined upper boundary and (2) the number of structural breaks is estimated for each $\mathrm{i}$ using an information criterion. ${ }^{2}$

The Bai and Perron (2003) iterative procedure is initiated with starting values for $\delta_{1 i}, \delta_{2 i}, \delta_{3 i}$ and $\delta_{4 i}$, by minimizing the objective function with respect to $\psi_{\mathrm{ij}}$ and $\tau_{\mathrm{ij}}$ while keeping $\delta_{1 i}, \delta_{2 i}, \delta_{3 i}$ and $\delta_{4 i}$, fixed, which requires an evaluation of the optimal break partition for all subsamples for the possibility of $\mathrm{m}_{\mathrm{i}}$ breaks. Because $\delta_{1 i}, \delta_{2 i}, \delta_{3 i}$ and $\delta_{4 i}$, are held fixed, this stage essentially minimizes the objective function of a pure structural change model. The next step is to minimize with respect to $\psi_{\mathrm{ij}}, \delta_{1 i}, \delta_{2 i}, \delta_{3 i}$ and $\delta_{4 i}$, simultaneously while keeping $\tau_{\mathrm{ij}}$ fixed. This iterative procedure continues until the marginal decrease in the objective function converges and produces a set of estimated breakpoints for each country $i$ in the sample. An issue with this test procedure is the assumption of cross-section independence. To address the impact of deviations from this assumption, Westerlund (2006) suggests using a bootstrap method following the sieve approach of Westerlund and Edgerton (2007). In this case, the cross-sectional and time series dependence of the disturbances can be approximated by means of a panel vector autoregressive model from which the bootstrap innovations are drawn. The Bai and Perron (2003) tests for cointegration are reported in Table 4. The empirical findings are in favour of the presence of cointegartion across the regions under study.

Table 4: Panel cointegration tests: Bai-Perron procedure

\begin{tabular}{lcc}
\hline Panel Cointegration & Statistic & Bootstrapped p-value \\
\hline Total & 7.348 & 0.69 \\
European Union & 6.451 & 0.73 \\
Asia & 8.905 & 0.70 \\
Latin America & 11.547 & 0.56 \\
Africa & 9.482 & 0.63 \\
\hline
\end{tabular}

Notes: Test results were estimated using the Bai and Perron (2003) procedure which tests the null hypothesis of cointegration. The p-value is based on the bootstrapped distribution. The number of lags in the sieve approximation is five with 1,000 bootstrap replications.

We proceed with the estimation of the long-run cointegration vector using the fully modified OLS (FMOLS) technique for heterogeneous cointegrated panels

\footnotetext{
${ }^{2}$ We use the Schwarz Bayesian criterion.
} 
(Pedroni, 1999, 2001). The results of the FMOLS estimates are reported in Table 5 which show that renewable energy displays some mixed results relatively to its impact on the unemployment rate. In particular, the overall results document that renewable energy seems to positively affect unemployment rates, implying the higher technological costs associated with this source of energy; therefore, the adoption of this form of energy source, under the present technology embodies in it, is expected to lead to higher costs of production, lower energy efficiency and, thus, to higher unemployment rates. These results remain consistent for the cases of the European Union and Africa. By contrast, in the cases of Asia and Latin America the empirical findings show that an increase in renewable energy consumption decreases the unemployment rate, implying that their economies seem to experience a positive shock or 'a job-creation' effect on their unemployment rates by using more energy coming from (specific) sources of renewables. The signs of the control variables are as expected from the literature. Table 5 also reports the cross-sectional dependence (CD) test, proposed by Pesaran (2004), which is valid for both small and large samples. ${ }^{3}$ The CD test results fail to reject the null hypothesis of cross-sectional independence at the $1 \%$ significance level, indicating that the cointegration residuals are not cross-sectional dependent. These results remain robust across all regions under investigation. However, the strongest effect on unemployment from the consumption of renewable energy is documented in the cases of the European Union and Latin America, yielding that these two particular regions not only have extended their energy consumption coming from renewable sources, but also that they invest more in the renewable industry.

${ }^{3}$ The cross-sectional dependence statistic is the $\mathrm{CD}=\sqrt{\frac{2 T}{N(N-1)}}\left(\sum_{i=1}^{N-1} \sum_{j=i+1}^{N} \hat{\rho}_{i j}\right) \rightarrow N(0,1)$. 
Table 5: FMOLS long-run panel estimates

\begin{tabular}{|c|c|c|}
\hline Variables & Coefficient Estimate & Bootstrapped p-value \\
\hline \multicolumn{3}{|l|}{ Total } \\
\hline $\mathrm{RE}$ & 0.352 & $0.018^{*}$ \\
\hline $\mathrm{K}$ & 0.368 & $0.024^{*}$ \\
\hline $\mathrm{E}$ & -0.141 & $0.022^{*}$ \\
\hline CREDIT & -0.296 & $0.025^{*}$ \\
\hline $\mathrm{G}$ & -0.357 & $0.018^{*}$ \\
\hline \multicolumn{3}{|c|}{ Adj $R^{2}=0.68 C D=0.579[p$-value $=0.21]$} \\
\hline \multicolumn{3}{|c|}{ European Union } \\
\hline $\mathrm{RE}$ & 0.469 & $0.012^{*}$ \\
\hline $\mathrm{K}$ & 0.402 & $0.025^{*}$ \\
\hline $\mathrm{E}$ & -0.236 & $0.019^{*}$ \\
\hline CREDIT & -0.218 & $0.021^{*}$ \\
\hline $\mathrm{G}$ & -0.548 & $0.007^{*}$ \\
\hline \multicolumn{3}{|c|}{ Adj $R^{2}=0.72 C D=0.684[p$-value $=0.33]$} \\
\hline Asia & -0.315 & $0.024^{*}$ \\
\hline $\mathrm{RE}$ & 0.366 & $0.018^{*}$ \\
\hline $\mathrm{K}$ & -0.285 & $0.013^{*}$ \\
\hline $\mathrm{E}$ & -0.241 & $0.029^{*}$ \\
\hline CREDIT & -0.169 & $0.037^{*}$ \\
\hline \multicolumn{3}{|l|}{$\mathrm{G}$} \\
\hline \multicolumn{3}{|c|}{ Adj $R^{2}=0.57 C D=0.524[p$-value $=0.29]$} \\
\hline \multicolumn{3}{|c|}{ Latin America } \\
\hline $\mathrm{RE}$ & -0.438 & $0.011^{*}$ \\
\hline $\mathrm{K}$ & 0.259 & $0.020^{*}$ \\
\hline $\mathrm{E}$ & -0.316 & $0.014^{*}$ \\
\hline CREDIT & -0.257 & $0.036^{*}$ \\
\hline $\mathrm{G}$ & -0.398 & $0.015^{*}$ \\
\hline \multicolumn{3}{|c|}{ Adj $R^{2}=0.61 C D=0.429[p$-value $=0.20]$} \\
\hline \multicolumn{3}{|l|}{ Africa } \\
\hline $\mathrm{RE}$ & 0.168 & $0.035^{*}$ \\
\hline $\mathrm{K}$ & 0.149 & $0.028^{*}$ \\
\hline $\mathrm{E}$ & -0.211 & $0.026^{*}$ \\
\hline CREDIT & -0.214 & $0.039^{*}$ \\
\hline $\mathrm{G}$ & -0.236 & $0.026^{*}$ \\
\hline $\operatorname{Adj} R^{2}=0$ & alue $=0.28]$ & \\
\hline
\end{tabular}

Notes: $5 \%$ significance level denoted by “*'. The p-values are based on the bootstrapped distribution. The number of bootstrap replications is 1,000 . CD is the cross-sectional dependence test, proposed by Pesaran (2004). 


\section{Panel Nonlinear Causality Results}

Given the long-run cointegrated relationships, we estimate a nonlinear panel smooth transition vector error correction model which takes into account that not only the adjustment to the long-run equilibrium, but the dynamic relationship between the variables might also be nonlinear. Following Gonzalez et al. (2005) and Omay and Kan (2010), we specify the panel smooth transition vector error correction model as follows:

$$
\Delta \mathbf{y}_{i t}=\beta_{i}+\theta^{\prime} \Delta X_{i t}+\sum_{j=1}^{r} \varphi_{j}^{\prime} X_{i t} G\left(s_{i t} ; \gamma, t\right)+\lambda E C_{i, t-1}+\eta_{i t}
$$

For $i=1,2, \cdots N$ and $t=1,2 \cdots T$ where $\mathrm{N}$ and $\mathrm{T}$ denote the cross-section and time dimensions of the panel, respectively. Here $X_{i t}=\left[\Delta U_{i t}, \Delta R E_{i t}, \Delta K_{i t}, \Delta E_{i t}, \Delta C R E D I T_{i t}, \Delta G_{i t},\right]$ and the spread out of this vector error correction model is presented in Appendix 2.

To address regime-shifts in the short-run and long-run, Gonzalez et al. (2005) and Omay and Kan (2010) consider the use of following logistic transition function:

$$
G\left(s_{i t}, \gamma, c\right)=\left[1+\exp \left(-\gamma \prod_{j=1}^{m}\left(s_{i t}-c_{j}\right)\right)\right]^{-1}
$$

with $\gamma>0$ and $c_{m} \geq \cdots \geq c_{1} \geq c_{0}$ where $c=\left(c_{1}, \cdots c_{m}\right)^{\prime}$ is a m-dimensional vector of location parameters and the slope parameter, $\gamma$, denotes the transition smoothness parameter between regimes. In the case where $\mathrm{m}=1$ (i.e., a first-order logistic transition function), the extreme regimes correspond to low and high values of $s_{i t}$ and the coefficients in equations (3)-(8) in Appendix 2 change smoothly as $s_{i t}$ increases. ${ }^{4}$ When $\gamma \rightarrow \infty$, the first-order logistic transition function becomes an indicator function $I(A)$ which takes a value of 1 when event $A$ occurs and 0 otherwise. Thus, the model reduces to Hansen's (1999) two-regime threshold model. For $\mathrm{m}=2$, on the other hand, the logistic transition function takes a value of 1 for both low and high values of $s_{i t}$, minimizing at $\left(c_{1}+c_{2}\right) / 2$. In that case, if $\gamma \rightarrow \infty$, the model reduces to a three-regime panel threshold model. ${ }^{5}$

\footnotetext{
${ }^{4} \mathrm{~A}$ value of 1 or 2 for $\mathrm{m}$ often meets the common types of variation.

${ }^{5}$ If $\gamma \rightarrow 0$, the logistic transition function reduces to a constant, hence the smooth transition panel model becomes a linear panel model for any value of $\mathrm{m}$.
} 
The procedure entails first specifying a linear panel model to test the null hypothesis of linearity against the alternative hypothesis of smooth transition nonlinearity. If linearity is rejected, we select the appropriate transition variable, $s_{i t}$, as well as the form of the transition function, $G\left(s_{i t} ; \gamma, c\right)$, that estimates the parameters of the selected panel smooth transition vector error correction model. To simplify estimations, the transition function may be replaced with the appropriate Taylor approximation (Luukkonen et al. 1988). For example, a $k^{t h}$-order Taylor approximation of the first-order logistic transition function around $\gamma=0$ results in the following auxiliary regression:

$$
\begin{aligned}
& \Delta z_{i t}=\lambda_{i}+\pi_{0}^{\prime} E C_{i t-1}+\sum_{j=1}^{p_{i}} \psi_{0 j} \Delta z_{i t-j}+\sum_{h=1}^{k} \pi_{h}^{\prime} s_{i t}^{h} E C_{i t-1}+\sum_{h=1}^{k} \sum_{j=1}^{p_{i}} \phi_{h j} s_{i t}^{h} \Delta z_{i t-j} \\
& +e_{i t}
\end{aligned}
$$

where $z_{i t}^{\prime}=\left(U_{i t}, R E_{i t}, K_{i t}, E_{i t}, C R E D I T_{i t}, G_{i t}\right)$ and $\lambda, \pi^{\prime}, \psi, \pi$ and $\phi$ are the functions of the parameters $\vartheta_{i}, \beta, \theta_{j}, \varphi_{j}, \beta_{j j}, \gamma$, and $\mathrm{c}$, while $e_{i t}$ comprises the original disturbance terms $\mu_{i t}$ as well as the error term arising from the Taylor approximation. Now, testing $\mathrm{H}_{0}: \gamma=0$ in equations (3)-(8) in Appendix 2 is equivalent to testing the null hypothesis $\mathrm{H}_{0}: \omega_{1}=\omega_{2}=\omega_{3}=0$, where $\omega_{\mathrm{i}} \equiv\left(\pi_{\mathrm{i}}, \phi_{\mathrm{i}}\right)$ in $(6)$. This test can be undertaken using an LM type test approximated by a F-distribution defined as follows:

$\mathrm{LM}=\frac{\left[\frac{\mathrm{SSR}_{0}-\mathrm{SSR}_{1}}{\mathrm{kp}}\right]}{\left[\frac{\mathrm{SSR}}{\mathrm{TN}-\mathrm{N}-\mathrm{k}(\mathrm{p}=1)}\right]} \sim \mathrm{F}(\mathrm{kp}, \mathrm{TN}-\mathrm{N}-\mathrm{k}(\mathrm{p}+1))$

where $\mathrm{SSR}_{0}$ and $\mathrm{SSR}_{1}$ are the sums of squared residuals under the null and alternative hypotheses, respectively. In order to choose the appropriate transition variable, $\mathrm{s}_{\mathrm{it}}$, the LM statistic is computed over alternative values of $s_{i t}$, with the selection based on the test statistic with the lowest probability value.

Once we select the appropriate transition variable, $s_{i t}$, we follow Terasvirta (1994) in testing a procedure that entails a sequence of tests based on auxiliary regression (6) with a $k$-th order Taylor approximation equal to 3 . We begin by testing the null hypothesis $\mathrm{H}_{0}: \omega_{1}=\omega_{2}=\omega_{3}=0$. If $\mathrm{H}_{0}$ rejected, we then test $\mathrm{H}_{03}: \omega_{3}=0$, followed by $\mathrm{H}_{02}: \omega_{2}=0 \mid \omega_{3}=0$ and $\mathrm{H}_{01}: \omega_{1}=0 \mid \omega_{2}=\omega_{3}=0$. These hypotheses are tested by ordinary F-tests, denoted as $F_{3}, F_{2}$, and $F_{1}$, respectively. Table 6 reports the 
probability values associated with the sequence of $F$ tests in the selection of the transition function. The smallest probability value associated with the $\mathrm{F}$ tests corresponds to F1 (a logistic function) as the appropriate transition function. The regime change in the panel smooth transition vector error correction model is governed by the transition function in which $\gamma$ determines the speed of the transition between the extreme regimes and c determines the midpoint of the transition. The estimated value of $\mathrm{c}$ is -0.00062 which is very close to zero, indicating that the extreme regimes correspond to the negative and positive values of the unemployment rate before and after the corresponding structural break. The estimated value of $\gamma$ is 1.329 , reflecting a rather smooth transition between regimes.

Table 6: Selection of the transition function

\section{Total}

\section{Break Date 1993}

Unemployment equation

F1

0.041

0.050

0.042

Capital equation

Real exchange rate equation

Credit equation

Government expenditures

equation

\section{Break Date 1997}

Unemployment equation

Renewable energy equation

Capital equation

Real exchange rate equation

Credit equation

Government expenditures

equation

\section{Break Date 2001}

Unemployment equation

Renewable energy equation

Capital equation

Real exchange rate equation

Credit equation

Government expenditures

equation

\section{F1}

0.037

0.042

0.057

0.043

0.057

0.041

\section{F1}

0.062

0.059

0.062

0.057

0.054

0.049
F2

0.075

0.094

0.081

0.086

0.098

0.087
F3

0.125

0.135

0.129

0.138

0.135

0.146

\section{Break Date 2008}

F2

0.071

0.084

0.112

0.082

0.118

0.076

\section{F3}

0.148

0.139

0.158

0.125

0.164

0.118 


\begin{tabular}{llll}
\hline Unemployment equation & 0.065 & 0.145 & 0.265 \\
Renewable energy equation & 0.058 & 0.139 & 0.224 \\
Capital equation & 0.072 & 0.152 & 0.293 \\
Real exchange rate equation & 0.061 & 0.163 & 0.285 \\
Credit equation & 0.054 & 0.132 & 0.194 \\
Government expenditures & 0.061 & 0.147 & 0.256 \\
equation & & &
\end{tabular}

\section{European Union \\ Break Date 1993}

Unemployment equation

F1

F2

F3

Renewable energy equation

0.048

0.064

0.132

0.055

0.106

0.148

0.053

0.121

0.175

Real exchange rate equation

0.060

0.109

0.185

0.056

0.138

0.214

0.063

0.137

0.263

Government expenditures

equation

\section{Break Date 2001}

Unemployment equation

F1

F2

F3

0.057

0.145

0.246

0.053

0.139

0.193

0.062

0.249

Capital equation

0.053

0.141

0.187

0.050

0.125

0.238

Credit equation

0.137

0.245

Government expenditures

equation

0.068

0.144

\section{Break Date 2009}

Unemployment equation

F1

F2

F3

0.053

0.152

0.264

0.057

0.145

0.264

Capital equation

0.062

0.263

0.052

0.141

0.248

Credit equation

0.064

0.135

0.256

0.057

0.148

0.263

Government expenditures

equation

0.142

\section{Asia}

\section{Break Date 1997}

Unemployment equation

F1

F2

F3

0.047

0.130

0.196

0.053

0.126

0.191

0.064

0.138

0.229

0.056

0.268

Real exchange rate equation

0.054

0.147

0.253

Government expenditures

0.046

0.149

0.186

Real exchange rate equation 
Break Date 2008

Unemployment equation

Renewable energy equation

0.040

0.125

0.163

0.046

0.099

0.126

Capital equation

0.095

0.122

Real exchange rate equation

0.093

0.134

Credit equation

0.051

0.092

0.118

Government expenditures

0.043

0.096

0.135

equation

\section{Latin America \\ Break Date 1999}

F1

0.045

0.048

0.044

0.050

0.046

0.049
F2

0.072

0.091

0.082

0.078

0.086

0.083
F3

0.117

0.124

0.118

0.126

0.109

0.123

equation

Break Date 2002

Unemployment equation

F1

0.043

0.056

0.040

0.047

0.053

0.045
F2

0.062

0.104

0.085

0.097

0.116

0.099
F3

0.095

0.129

0.136

0.146

0.169

0.138

Government expenditures

equation

\section{Break Date 2006}

Unemployment equation

F1

F2

F3

0.045

0.093

0.156

0.052

0.110

0.162

Capital equation

0.045

0.096

0.147

Real exchange rate equation

0.055

0.116

0.160

Credit equation

0.054

0.129

0.181

Government expenditures

0.045

0.115

0.173

\section{Break Date 2008}

Unemployment equation

F1

0.054

0.052

0.049

0.052

0.058

0.043
F2

0.089

0.124

0.125

0.127

0.114

0.095

\section{F3}

0.156

0.189

0.219

0.194

0.180

0.165 
equation

Africa

Break Date 2002

$\begin{array}{lll}\text { F1 } & \text { F2 } & \text { F3 }\end{array}$

$\begin{array}{llll}\text { Unemployment equation } & 0.052 & 0.089 & 0.146\end{array}$

$\begin{array}{llll}\text { Renewable energy equation } & 0.051 & 0.106 & 0.173\end{array}$

$\begin{array}{llll}\text { Capital equation } & 0.054 & 0.131 & 0.194\end{array}$

$\begin{array}{llll}\text { Real exchange rate equation } & 0.050 & 0.128 & 0.211\end{array}$

$\begin{array}{llll}\text { Credit equation } & 0.045 & 0.116 & 0.182\end{array}$

$\begin{array}{llll}\text { Government expenditures } & 0.045 & 0.103 & 0.178\end{array}$

equation

Break Date 2007

Unemployment equation

$\begin{array}{lll}\text { F1 } & \text { F2 } & \text { F3 }\end{array}$

$\begin{array}{llll}\text { Renewable energy equation } & 0.052 & 0.114 & 0.182\end{array}$

$\begin{array}{llll}\text { Capital equation } & 0.049 & 0.124 & 0.195\end{array}$

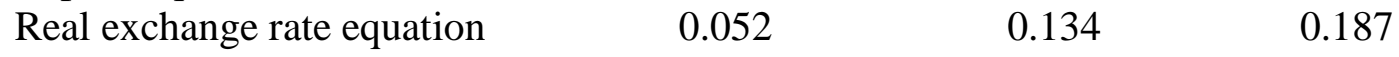

$\begin{array}{llll}\text { Credit equation } & 0.043 & 0.118 & 0.176\end{array}$

$\begin{array}{llll}\text { Government expenditures } & 0.041 & 0.120 & 0.215\end{array}$

equation

Notes: Reported numbers are probability values. The p-values are based on the bootstrapped distribution. The number of bootstrap replications is 1,000 .

With allowance for regime-dependent dynamics between the variables, we follow $\mathrm{Li}$ (2006) by conducting the Granger causality tests separately for each regime. ${ }^{6}$ The null hypotheses of no Granger-causality can be formulated for the unemployment rate and the renewable energy consumption per capita (i.e., focusing on equations 3 and 4 in Appendix 2) as follows: (1) renewable energy consumption does not Granger cause the unemployment rate for the pre-period in the short-run, $\mathrm{H}_{0}: \theta_{12}=0$; (2) the unemployment rate does not Granger cause renewable energy consumption for the pre-period in the long-run, $\mathrm{H}_{0}: \lambda_{1}=0$ and/or $\lambda_{1}=\theta_{12}=0$; (3) the unemployment rate does not Granger cause renewable energy consumption for the post-period in the short-run, $\mathrm{H}_{0}: \theta_{12}=\varphi_{12}=0$; and (4) the unemployment rate does not Granger cause renewable energy consumption for the post-period in the long-run, $H_{0}: \lambda_{1}=\lambda_{11}=0$ and/or $\lambda_{1}=\lambda_{11}=\theta_{12}=\varphi_{12}=0$. Similarly, the short-run and long-run null hypotheses of the absence of Granger-causality can be readily applied to the remaining equations

\footnotetext{
6 Although the number of observations over some post-periods is much less than pre-period, Westerlund (2006) has shown the asymptotic properties are borne out well even in small samples.
} 
specified in the panel smooth transition vector error correction model. The regimewise Granger causality findings are reported in Table 7.

The results in Table 7 indicate unidirectional causality from renewable energy to unemployment at the aggregate level in post-1993, post-1997, pre-2008 and post-2008 both in short and long run. Interesting results emerge when we conduct region-wise causality analysis. The results reported in Table 7 show that there are unidirectional causality from renewable energy consumption to unemployment in the European Union, Asia and the Latin American countries in different sub-periods. However, we find no causality in either direction on any sub-period in African region. Heterogeneous results in various regions perhaps because of differences in renewable energy portfolio standards, labour market conditions and government policies toward sustainable development. 
Table 7: Regime-wise Granger-causality tests

\begin{tabular}{|c|c|c|}
\hline $\begin{array}{l}\text { Aggregate } \\
\text { Pre-1993 Period }\end{array}$ & Short-Run & Long-Run \\
\hline RE does not Granger cause U & $\begin{array}{c}1.18 \\
{[0.52]}\end{array}$ & $\begin{array}{l}-0.003 \\
{[0.87]}\end{array}$ \\
\hline $\mathrm{U}$ does not Granger cause RE & $\begin{array}{c}2.26 \\
{[0.24]}\end{array}$ & $\begin{array}{l}-0.012 \\
{[0.47]}\end{array}$ \\
\hline $\begin{array}{l}\text { Post-1993 Period } \\
\text { RE does Granger cause U }\end{array}$ & $\begin{array}{l}28.35 \\
{[0.00]^{*}}\end{array}$ & $\begin{array}{l}-0.136 \\
{[0.00]^{*}}\end{array}$ \\
\hline $\mathrm{U}$ does not Granger cause RE & $\begin{array}{c}2.14 \\
{[0.29]}\end{array}$ & $\begin{array}{l}-0.039 \\
{[0.26]}\end{array}$ \\
\hline $\begin{array}{l}\text { Pre-1997 Period } \\
\text { RE does not Granger cause U }\end{array}$ & $\begin{array}{c}1.59 \\
{[0.41]}\end{array}$ & $\begin{array}{l}-0.007 \\
{[0.77]}\end{array}$ \\
\hline $\mathrm{U}$ does not Granger cause RE & $\begin{array}{c}1.65 \\
{[0.40]}\end{array}$ & $\begin{array}{l}-0.017 \\
{[0.42]}\end{array}$ \\
\hline $\begin{array}{l}\text { Post-1997 Period } \\
\text { RE does Granger cause U }\end{array}$ & $\begin{array}{c}26.48 \\
{[0.00]^{*}}\end{array}$ & $\begin{array}{l}-0.151 \\
{[0.00]^{*}}\end{array}$ \\
\hline $\mathrm{U}$ does not Granger cause RE & $\begin{array}{c}2.09 \\
{[0.34]}\end{array}$ & $\begin{array}{l}-0.035 \\
{[0.31]}\end{array}$ \\
\hline $\begin{array}{l}\text { Pre-2001 Period } \\
\text { RE does not Granger cause U }\end{array}$ & $\begin{array}{c}1.54 \\
{[0.36]}\end{array}$ & $\begin{array}{l}-0.026 \\
{[0.58]}\end{array}$ \\
\hline $\mathrm{U}$ does not Granger cause RE & $\begin{array}{c}0.83 \\
{[0.89]}\end{array}$ & $\begin{array}{l}-0.015 \\
{[0.73]}\end{array}$ \\
\hline $\begin{array}{l}\text { Pre-2008 Period } \\
\text { RE does Granger cause U }\end{array}$ & $\begin{array}{l}5.62 \\
{[0.10]^{* * *}}\end{array}$ & $\begin{array}{l}-0.036 \\
{[0.09]^{* * *}}\end{array}$ \\
\hline $\mathrm{U}$ does not Granger cause RE & $\begin{array}{c}2.25 \\
{[0.30]}\end{array}$ & $\begin{array}{l}-0.016 \\
{[0.43]}\end{array}$ \\
\hline $\begin{array}{l}\text { Post-2008 Period } \\
\text { RE does Granger cause U }\end{array}$ & $\begin{array}{c}67.93 \\
{[0.00]^{*}}\end{array}$ & $\begin{array}{l}-0.248 \\
{[0.00]^{*}}\end{array}$ \\
\hline U does not Granger cause RE & $\begin{array}{c}2.81 \\
{[0.23]}\end{array}$ & $\begin{array}{l}-0.035 \\
{[0.19]}\end{array}$ \\
\hline $\begin{array}{l}\text { European Union } \\
\text { Pre-1993 Period }\end{array}$ & & \\
\hline RE does not Granger cause U & $\begin{array}{c}1.25 \\
{[0.46]}\end{array}$ & $\begin{array}{l}-0.005 \\
{[0.84]}\end{array}$ \\
\hline U does not Granger cause RE & $\begin{array}{c}1.55 \\
{[0.38]}\end{array}$ & $\begin{array}{l}-0.010 \\
{[0.44]}\end{array}$ \\
\hline $\begin{array}{l}\text { Post-1993 Period } \\
\text { RE does Granger cause U }\end{array}$ & $\begin{array}{c}26.39 \\
{[0.00]^{*}}\end{array}$ & $\begin{array}{l}-0.084 \\
{[0.02]^{*}}\end{array}$ \\
\hline $\mathrm{U}$ does not Granger cause RE & $\begin{array}{c}1.45 \\
{[0.24]}\end{array}$ & $\begin{array}{l}-0.024 \\
{[0.32]}\end{array}$ \\
\hline
\end{tabular}




\begin{tabular}{|c|c|c|}
\hline $\begin{array}{l}\text { Pre-2001 Period } \\
\text { RE does not Granger cause U }\end{array}$ & $\begin{array}{c}4.52 \\
{[0.11]}\end{array}$ & $\begin{array}{l}-0.024 \\
{[0.35]}\end{array}$ \\
\hline $\mathrm{U}$ does not Granger cause RE & $\begin{array}{c}1.09 \\
{[0.38]}\end{array}$ & $\begin{array}{l}-0.008 \\
{[0.66]}\end{array}$ \\
\hline $\begin{array}{l}\text { Post-2001 Period } \\
\text { RE does Granger cause U }\end{array}$ & $\begin{array}{c}40.53 \\
{[0.00]^{*}}\end{array}$ & $\begin{array}{l}-0.152 \\
{[0.00]^{*}}\end{array}$ \\
\hline U does not Granger cause RE & $\begin{array}{c}2.60 \\
{[0.24]}\end{array}$ & $\begin{array}{l}-0.027 \\
{[0.38]}\end{array}$ \\
\hline $\begin{array}{l}\text { Pre-2009 Period } \\
\text { RE does Granger cause U }\end{array}$ & $\begin{array}{l}8.35 \\
{[0.09]^{* * *}}\end{array}$ & $\begin{array}{l}-0.046 \\
{[0.07]^{* * * *}}\end{array}$ \\
\hline U does not Granger cause RE & $\begin{array}{c}2.58 \\
{[0.21]}\end{array}$ & $\begin{array}{l}-0.029 \\
{[0.15]}\end{array}$ \\
\hline $\begin{array}{l}\text { Post-2009 Period } \\
\text { RE does Granger cause U }\end{array}$ & $\begin{array}{c}74.38 \\
{[0.00]^{*}}\end{array}$ & $\begin{array}{c}-0.297 \\
{[0.00]^{*}}\end{array}$ \\
\hline U does not Granger cause RE & $\begin{array}{c}3.45 \\
{[0.15]}\end{array}$ & $\begin{array}{l}-0.032 \\
{[0.28]}\end{array}$ \\
\hline $\begin{array}{l}\text { Asia } \\
\text { Pre-1997 Period } \\
\text { RE does not Granger cause U }\end{array}$ & $\begin{array}{c}2.53 \\
{[0.46]}\end{array}$ & $\begin{array}{l}-0.010 \\
{[0.78]}\end{array}$ \\
\hline $\mathrm{U}$ does not Granger cause RE & $\begin{array}{c}1.03 \\
{[0.51]}\end{array}$ & $\begin{array}{l}-0.004 \\
{[0.64]}\end{array}$ \\
\hline $\begin{array}{l}\text { Post-1997 Period } \\
\text { RE does Granger cause U }\end{array}$ & $\begin{array}{c}22.49 \\
{[0.00]^{*}}\end{array}$ & $\begin{array}{c}-0.074 \\
{[0.00]^{*}}\end{array}$ \\
\hline U does not Granger cause RE & $\begin{array}{c}1.48 \\
{[0.35]}\end{array}$ & $\begin{array}{l}-0.016 \\
{[0.39]}\end{array}$ \\
\hline $\begin{array}{l}\text { Pre-2008 Period } \\
\text { RE does Granger cause U }\end{array}$ & $\begin{array}{l}6.70 \\
{[0.10]^{* * *}}\end{array}$ & -0.042 \\
\hline U does not Granger cause RE & $\begin{array}{c}1.15 \\
{[0.46]}\end{array}$ & $\begin{array}{c}-0.016 \\
{[0.40]}\end{array}$ \\
\hline $\begin{array}{l}\text { Post-2008 Period } \\
\text { RE does Granger cause U }\end{array}$ & $\begin{array}{c}39.81 \\
{[0.00]^{*}}\end{array}$ & $\begin{array}{l}-0.145 \\
{[0.00]^{*}}\end{array}$ \\
\hline U does not Granger cause RE & $\begin{array}{c}2.26 \\
{[0.24]}\end{array}$ & $\begin{array}{l}-0.033 \\
{[0.28]}\end{array}$ \\
\hline $\begin{array}{l}\text { Latin America } \\
\text { Pre-1999 Period }\end{array}$ & & \\
\hline RE does not Granger cause U & $\begin{array}{c}3.52 \\
{[0.22]}\end{array}$ & $\begin{array}{c}-0.019 \\
{[0.35]}\end{array}$ \\
\hline U does not Granger cause RE & $\begin{array}{c}0.75 \\
{[0.63]}\end{array}$ & $\begin{array}{l}-0.006 \\
{[0.80]}\end{array}$ \\
\hline $\begin{array}{l}\text { Post-1999 Period } \\
\text { RE does Granger cause U }\end{array}$ & $\begin{array}{c}14.55 \\
{[0.02]^{*}}\end{array}$ & $\begin{array}{l}-0.058 \\
{[0.05]^{*}}\end{array}$ \\
\hline
\end{tabular}




\begin{tabular}{|c|c|c|}
\hline U does not Granger cause RE & $\begin{array}{c}1.64 \\
{[0.23]}\end{array}$ & $\begin{array}{l}-0.037 \\
{[0.25]}\end{array}$ \\
\hline $\begin{array}{l}\text { Pre-2002 Period } \\
\text { RE does not Granger cause U }\end{array}$ & $\begin{array}{c}4.72 \\
{[0.35]}\end{array}$ & $\begin{array}{l}-0.022 \\
{[0.20]}\end{array}$ \\
\hline U does not Granger cause RE & $\begin{array}{c}1.13 \\
{[0.42]}\end{array}$ & $\begin{array}{l}-0.038 \\
{[0.23]}\end{array}$ \\
\hline $\begin{array}{l}\text { Post-2002 Period } \\
\text { RE does Granger cause U }\end{array}$ & $\begin{array}{c}34.51 \\
{[0.00]^{*}}\end{array}$ & $\begin{array}{l}-0.125 \\
{[0.00]^{*}}\end{array}$ \\
\hline RE does not Granger cause U & $\begin{array}{c}2.38 \\
{[0.24]}\end{array}$ & $\begin{array}{l}-0.028 \\
{[0.35]}\end{array}$ \\
\hline $\begin{array}{l}\text { Pre-2006 Period } \\
\text { RE does Granger cause U }\end{array}$ & $\begin{array}{l}9.74 \\
{[0.06]^{* *}}\end{array}$ & $\begin{array}{c}-0.084 \\
{[0.05]^{* *}}\end{array}$ \\
\hline U does not Granger cause RE & $\begin{array}{c}2.35 \\
{[0.20]}\end{array}$ & $\begin{array}{l}-0.016 \\
{[0.31]}\end{array}$ \\
\hline $\begin{array}{l}\text { Post-2006 Period } \\
\text { RE does Granger cause U }\end{array}$ & $\begin{array}{l}54.26 \\
{[0.00]^{*}}\end{array}$ & $\begin{array}{l}-0.205 \\
{[0.00]^{*}}\end{array}$ \\
\hline U does not Granger cause RE & $\begin{array}{c}1.63 \\
{[0.38]}\end{array}$ & $\begin{array}{l}-0.017 \\
{[0.41]}\end{array}$ \\
\hline $\begin{array}{l}\text { Pre-2008 Period } \\
\text { RE does Granger cause U }\end{array}$ & $\begin{array}{l}12.53 \\
{[0.02]^{*}}\end{array}$ & $\begin{array}{c}-0.116 \\
{[0.00]^{*}}\end{array}$ \\
\hline U does not Granger cause RE & $\begin{array}{c}2.14 \\
{[0.27]}\end{array}$ & $\begin{array}{l}-0.016 \\
{[0.36]}\end{array}$ \\
\hline $\begin{array}{l}\text { Post-2008 Period } \\
\text { RE does Granger cause U }\end{array}$ & $\begin{array}{l}70.47 \\
{[0.00]^{*}}\end{array}$ & $\begin{array}{l}-0.228 \\
{[0.00]^{*}}\end{array}$ \\
\hline U does not Granger cause RE & $\begin{array}{c}2.39 \\
{[0.22]}\end{array}$ & $\begin{array}{l}-0.035 \\
{[0.23]}\end{array}$ \\
\hline $\begin{array}{l}\text { Africa } \\
\text { Pre-2002 Period }\end{array}$ & & \\
\hline RE does not Granger cause U & $\begin{array}{c}1.52 \\
{[0.46]}\end{array}$ & $\begin{array}{l}-0.019 \\
{[0.11]}\end{array}$ \\
\hline U does not Granger cause RE & $\begin{array}{c}1.64 \\
{[0.21]}\end{array}$ & $\begin{array}{l}-0.028 \\
{[0.25]}\end{array}$ \\
\hline Post-2002 Period & & \\
\hline RE does not Granger cause U & $\begin{array}{c}5.61 \\
{[0.19]}\end{array}$ & $\begin{array}{l}-0.045 \\
{[0.20]}\end{array}$ \\
\hline U does not Granger cause RE & $\begin{array}{c}1.48 \\
{[0.28]}\end{array}$ & $\begin{array}{l}-0.032 \\
{[0.22]}\end{array}$ \\
\hline Pre-2007 Period & & \\
\hline RE does not Granger cause U & $\begin{array}{c}6.83 \\
{[0.12]}\end{array}$ & $\begin{array}{l}-0.053 \\
{[0.17]}\end{array}$ \\
\hline U does not Granger cause RE & $\begin{array}{c}0.72 \\
{[0.62]}\end{array}$ & $\begin{array}{l}-0.010 \\
{[0.53]}\end{array}$ \\
\hline
\end{tabular}




\begin{tabular}{lcc}
\hline Post-2007 Period & 8.48 & -0.057 \\
RE does not Granger cause U & {$[0.11]$} & {$[0.14]$} \\
& 1.02 & -0.015 \\
U does not Granger cause RE & {$[0.47]$} & {$[0.46]$} \\
\hline
\end{tabular}

Notes: Partial $F$-statistics reported with respect to short-run changes in the independent variables. EC represents the respective error correction terms. Probability values are in brackets and reported underneath the corresponding partial $F$-statistic. Significance levels: * (1\%), **b (5\%), and *** (10\%).

\section{Conclusions and policy implications}

The increasing awareness of climate change and its consequences has led to a new assessment of the different routes to $\mathrm{CO} 2$-mitigation. Among other options, the possible contributions of renewable energy and its costs are under scrutiny. Our paper contributes to the discussion on the dynamic nexus of renewable energy consumption and unemployment by incorporating non-linear cointegration and causality analysis. The use of second generation unit root and cointegration techniques in panel data allow us to better characterise the order of integration of variables used in the model and thereby provide more robust cointegration and causality analyses compared to earlier studies. More specifically the recently developed unit root test by Carrion-iSilvestre et al. (2005), CSD test by Pesaran (2004) and panel cointegration test by Westerlund (2006) which account for structural breaks and cross sectional dependence. In addition, we employed a novel technique to take into account nonlinear dynamic relationship between variables in the long-run by following Gonzalez et al. (2005), and Omay and Kan (2010). Accounting for cross-sectional dependence, we find that renewable energy consumption positively affects unemployment in the European Union and Africa implying that higher technological cost associated with this source of energy.

By contrast, the empirical results show that the increase in renewable energy consumption decrease unemployment in Asia and Latin American countries. These results imply that these economies seem to have job creation effect with the use of energy from renewable sources. In addition, non-linear estimates from Granger causality results highlight a mixed picture. In particular, both for the total outcome and across regions, the causality results highlight the presence of a univariate causality running from renewable energy consumption to unemployment, only, however, as long as the recent time period is approached. This period seems to be 
closely associated with specific activities in favour of renewable energy that occurred across the regions under study.

However, any employment gains do not occur by default, but rather by design. They result from a mix of policy and investment decisions which are very much country-and-context-specific. Policies must set job creation as a goal in itself, not just assumed to be an immediate consequence of growth - even when it is labelled green growth. Therefore, to ensure the positive character of the effect of renewable energy consumption on reducing unemployment a variety of policies has to be deployed in countries across the world. The main policies which could drive a job-rich transformation to greener economies are associated with macroeconomic policies, aimed at redirecting consumption and investment through price signals and incentives for enterprises, consumers and investors, including taxation, price guarantees, subsidies, finance and public investment, sectoral policies for key economic sectors or important groups of enterprises, such as small medium enterprises. This includes most environmental regulation as well as mandates (such as the share of renewable energy in power supply, energy efficiency standards, or biodiversity set-asides in agriculture and forestry), and, finally, social and labour policies, which ideally include a combination of social protection, employment, skills development and active labour market policies. In relevance to latter group of policies, it is of particular importance the building and upgrading of skills for green jobs. The transition to a greener economy requires new skills both for new occupations as well as for transformed occupations. Firms investing in new technologies need to be able to find workers with the right skills. This implies that countries need strategies that align their energy, environment, education and skills development objectives and policies leading to programmes for potential skills upgrading and the redesigning of national vocational training and education schemes.

Finally, more research and understanding is needed on how green growth might affect different categories of workers and the distributional impact across society. This indicates to the importance of social protection, and social safeguards. For green growth to enhance social inclusion, dedicated social and labour market policies will need to complement economic and environmental policies. Several countries have attempted innovative social protection mechanisms and conditional cash transfers, allowing communities affected by greening policies to find alternative sources of livelihood and low-skilled workers to secure an income. 


\section{Appendix 1: 80 country panel}

Algeria, Argentina, Australia, Austria, Bangladesh, Belgium, Bolivia, Brazil, Bulgaria, Canada, Cameron, Chile, China, Comoros, Costa Rica, Denmark, Dominican Republic, Ecuador, Egypt, El Salvador, Ethiopia, Finland, France, Gabon, Germany, Ghana, Greece, Guatemala, Guinea, Honduras, Hungary, Iceland, India, Indonesia, Iran, Ireland, Italy, Japan, Jordan, Kenya, Korea, Luxembourg, Madagascar, Malawi, Malaysia, Mali, Mauritius, Mexico, Morocco, Mozambique, Netherlands, New Zealand, Nicaragua, Norway, Pakistan, Panama, Paraguay, Peru, Philippines, Poland, Portugal, Romania, Senegal, South Africa, Spain, Sri Lanka, Sudan, Swaziland, Sweden, Switzerland, Syria, Thailand, Tunisia, Turkey, Uganda, United Kingdom, United States, Uruguay, Venezuela, Zambia.

\section{Appendix 2: Spread out of the vector error correction model}

$$
\begin{aligned}
& \Delta U_{i t}=\beta_{1}+\sum_{j=1}^{p_{1 i}} \theta_{11 i j} \Delta U_{i, t-j}+\sum_{j=1}^{p_{2 i}} \theta_{12 i j} \Delta R E_{i, t-j}+\sum_{j=1}^{p_{3 i}} \theta_{i 3 i j} \Delta K_{i, t-j} \sum_{j=1}^{p_{4 i}} \theta_{14 i j} \Delta E_{i, t-j}+ \\
& \sum_{j=1}^{p_{5 i}} \theta_{15 i j} \Delta C R E D I T_{i, t-j}+\sum_{j=1}^{p 6 i} \theta_{16 i j} \Delta G_{i, t-j}+G\left(s_{i t} ; \gamma, t\right)\left[\lambda_{11 i} E C_{i t-1}+\sum_{j=1}^{p 1 i} \varphi_{11 i j} \Delta U_{i, t-j}+\right. \\
& \sum_{j=1}^{p 2 i} \varphi_{12 i j} \Delta R E_{i, t-j}+\sum_{j=1}^{p 3 i} \varphi_{13 i j} \Delta K_{i, t-j}+\sum_{j=1}^{p 4 i} \varphi_{14 i j} \Delta E_{i, t-j}+\sum_{j=1}^{p 5 i} \varphi_{15 i j} \Delta C R E D I T_{i, t-j}+ \\
& \left.\sum_{j=1}^{p 6 i} \varphi_{16 i j} \Delta G_{i, t-j}\right]+\lambda_{1 i} E C_{i, t-1}+\eta_{1 i} \\
& \Delta R E_{i t}=\beta_{2}+\sum_{j=1}^{p_{1 i}} \theta_{21 i j} \Delta U_{i, t-j}+\sum_{j=1}^{p_{2 i}} \theta_{221 i j} \Delta R E_{i, t-j}+\sum_{j=1}^{p_{3 i}} \theta_{23 i j} \Delta K_{i, t-j}+\sum_{j=1}^{p_{4 i}} \theta_{24 i j} \Delta E_{i, t-j}+ \\
& \sum_{j=1}^{p_{5 i}} \theta_{25 i j} \Delta C R E D I T_{i, t-j}+\sum_{j=1}^{p_{6 i}} \theta_{26 i j} \Delta G_{i, t-j}+G\left(s_{i t} ; \gamma, t\right)\left[\lambda_{22 i} E C_{i t-1}+\sum_{j=1}^{p 1 i} \varphi_{21 i j} \Delta U_{i, t-j}+\right. \\
& \sum_{j=1}^{p 2 i} \varphi_{22 i j} \Delta R E_{i, t-j}+\sum_{j=1}^{p 3 i} \varphi_{23 i j} \Delta K_{i, t-j}+\sum_{j=1}^{p 4 i} \varphi_{24 i j} \Delta E_{i, t-j}+\sum_{j=1}^{p 5 i} \varphi_{25 i j} \Delta C R E D I T_{i, t-j}+ \\
& \left.\sum_{j=1}^{p 6 i} \varphi_{26 i j} \Delta G_{i, t-j}\right]+\lambda_{2 i} E C_{i, t-1}+\eta_{2 i} \\
& \Delta K_{i t}=\beta_{3}+\sum_{j=1}^{p_{1 i}} \theta_{31 i j} \Delta U_{i, t-j}+\sum_{j=1}^{p_{2 i}} \theta_{321 i j} \Delta R E_{i, t-j}+\sum_{j=1}^{p_{3 i}} \theta_{33 i j} \Delta K_{i, t-j}+\sum_{j=1}^{p_{4 i}} \theta_{34 i j} \Delta E_{i, t-j}+ \\
& \sum_{j=1}^{p_{5 i}} \theta_{35 i j} \Delta C R E D I T_{i, t-j}+\sum_{j=1}^{p_{6 i}} \theta_{36 i j} \Delta G_{i, t-j}+G\left(s_{i t} ; \gamma, t\right)\left[\lambda_{33 i} E C_{i t-1}+\sum_{j=1}^{p 1 i} \varphi_{31 i j} \Delta U_{i, t-j}+\right. \\
& \sum_{j=1}^{p 2 i} \varphi_{32 i j} \Delta R E_{i, t-j}+\sum_{j=1}^{p 3 i} \varphi_{33 i j} \Delta K_{i, t-j}+\sum_{j=1}^{p 4 i} \varphi_{34 i j} \Delta E_{i, t-j}+\sum_{j=1}^{p 5 i} \varphi_{35 i j} \Delta C R E D I T_{i, t-j}+ \\
& \left.\sum_{j=1}^{p 6 i} \varphi_{36 i j} \Delta G_{i, t-j}\right]+\lambda_{3 i} E C_{i, t-1}+\eta_{3 i}
\end{aligned}
$$




$$
\begin{aligned}
& \Delta E_{i t}=\beta_{4}+\sum_{j=1}^{p_{1 i}} \theta_{41 i j} \Delta U_{i, t-j}+\sum_{j=1}^{p_{2 i}} \theta_{421 i j} \Delta R E_{i, t-j}+\sum_{j=1}^{p_{3 i}} \theta_{43 i j} \Delta K_{i, t-j}+\sum_{j=1}^{p_{4 i}} \theta_{44 i j} \Delta E_{i, t-j}+ \\
& \sum_{j=1}^{p_{5 i}} \theta_{45 i j} \Delta C R E D I T_{i, t-j}+\sum_{j=1}^{p_{6 i}} \theta_{46 i j} \Delta G_{i, t-j}+G\left(s_{i t} ; \gamma, t\right)\left[\lambda_{44 i} E C_{i t-1}+\sum_{j=1}^{p 1 i} \varphi_{41 i j} \Delta U_{i, t-j}+\right. \\
& \sum_{j=1}^{p 2 i} \varphi_{42 i j} \Delta R E_{i, t-j}+\sum_{j=1}^{p 3 i} \varphi_{43 i j} \Delta K_{i, t-j}+\sum_{j=1}^{p 4 i} \varphi_{44 i j} \Delta E_{i, t-j}+\sum_{j=1}^{p 5 i} \varphi_{45 i j} \Delta C R E D I T_{i, t-j}+ \\
& \left.\sum_{j=1}^{p 6 i} \varphi_{46 i j} \Delta G_{i, t-j}\right]+\lambda_{3 i} E C_{i, t-1}+\eta_{4 i}
\end{aligned}
$$

$$
\begin{gathered}
\Delta C R E D I T_{i t}=\beta_{5}+\sum_{j=1}^{p_{1 i}} \theta_{51 i j} \Delta U_{i, t-j}+\sum_{j=1}^{p_{2 i}} \theta_{52 i j} \Delta R E_{i, t-j}+\sum_{j=1}^{p_{3 i}} \theta_{53 i j} \Delta K_{i, t-j}+\sum_{j=1}^{p_{4 i}} \theta_{54 i j} \Delta E_{i, t-j}+ \\
\sum_{j=1}^{p 5 i} \theta_{55 i j} \Delta C R E D I T_{i, t-j}+\sum_{j=1}^{p 6 i} \theta_{56 i j} \Delta G_{i, t-j}+G\left(s_{i t} ; \gamma, t\right)\left[\lambda_{55 i} E C_{i t-1}+\sum_{j=1}^{p 1 i} \varphi_{51 i j} \Delta U_{i, t-j}+\right. \\
\sum_{j=1}^{p 2 i} \varphi_{52 i j} \Delta R E_{i, t-j}+\sum_{j=1}^{p 3 i} \varphi_{53 i j} \Delta K_{i, t-j}+\sum_{j=1}^{p 4 i} \varphi_{54 i j} \Delta E_{i, t-j}+\sum_{j=1}^{p 5 i} \varphi_{55 i j} \Delta C R E D I T_{i, t-j}+ \\
\left.\sum_{j=1}^{p 6 i} \varphi_{56 i j} \Delta G_{i, t-j}\right]+\lambda_{5 i} E C_{i, t-1}+\eta_{5 i}
\end{gathered}
$$

$$
\begin{aligned}
\Delta G_{i t}= & \beta_{6}+\sum_{j=1}^{p_{1 i}} \theta_{61 i j} \Delta U_{i, t-j}+\sum_{j=1}^{p_{2 i}} \theta_{62 i j} \Delta R E_{i, t-j}+\sum_{j=1}^{p_{3 i}} \theta_{63 i j} \Delta K_{i, t-j}+\sum_{j=1}^{p_{4 i}} \theta_{64 i j} \Delta E_{i, t-j}+ \\
& \sum_{j=1}^{p 5 i} \theta_{65 i j} \Delta C R E D I T_{i, t-j}+\sum_{j=1}^{p 6 i} \theta_{66 i j} \Delta G_{i, t-j}+G\left(s_{i t} ; \gamma, t\right)\left[\lambda_{66 i} E C_{i t-1}+\sum_{j=1}^{p 1 i} \varphi_{61 i j} \Delta U_{i, t-j}+\right. \\
& \sum_{j=1}^{p 2 i} \varphi_{62 i j} \Delta R E_{i, t-j}+\sum_{j=1}^{p 3 i} \varphi_{63 i j} \Delta K_{i, t-j}+\sum_{j=1}^{p 4 i} \varphi_{64 i j} \Delta E_{i, t-j}+\sum_{j=1}^{p 5 i} \varphi_{65 i j} \Delta C R E D I T_{i, t-j}+ \\
& \left.\sum_{j=1}^{p 6 i} \varphi_{66 i j} \Delta G_{i, t-j}\right]+\lambda_{6 i} E C_{i, t-1}+\eta_{6 i}
\end{aligned}
$$

Here $i=1, \ldots, N$ and $t=1, \ldots, T$ where $\mathrm{N}$ and $\mathrm{T}$ denote the cross-section and time dimensions of the panel, respectively; $\vartheta_{i}$ represents fixed individual effects; $E C_{i t}$ is the error correction term from the cointegration vector; and $\mu_{i t}$ is the error term assumed to be a martingale difference with respect to the history of the vector of variables with mean zero and variance, $\sigma_{i}^{2}$. 


\section{References}

Apergis, N., Payne, J.E., 2012. Renewable and non-renewable energy consumptiongrowth nexus: evidence from a panel error correction model. Energy Economics, 34, 733-738.

Bai, J. and Perron, P. (2003) Computation and Analysis of Multiple Structural Change Models, Journal of Applied Econometrics 18, 1-22.

Carrion-i-Silvestre, J.L., T.D. Barrio-Castro, and E. Lopez-Bazo (2005) Breaking the Panels: An Application to the GDP Per Capita, Econometrics Journal, 8, 159175.

Dickey, D., Fuller, W. (1979) Distribution of the estimators for autoregressive time series with a unit root. Journal of the American Statistical Association 74, 427-431.

Elliott, G., Rothenberg, T.J. and Stock, J.H. (1996), "Efficient tests for an autoregressive unit root", Econometrica 64, 813-836.

Gan, J., Smith, CT. 2011. Drivers for renewable energy: a comparison among OECD countries. Biomass and Bioenergy 35, 4497-4503.

Gonzalez, A., T. Terasvirta, and D. Dijk (2005) Panel Smooth Transition Regression Models. Working Paper Series in Economics and Finance No. 604, Stockholm School of Economics, Sweden.

Gülen, G. (2010). Defining, Measuring and Predicting Green Jobs. Working Paper, Copenhagen Consensus Centre.

Hansen, B.E. (1999) Threshold Effects in Non-Dynamic Panels: Estimation, Testing, and Inference. Journal of Econometrics, 93, 345-368.

Im, K., Pesaran, M. and Shin, Y. (2003) Testing for unit roots in heterogeneous panels. Journal of Econometrics 115, 53-74.

Im, K.S., Lee, J., Tieslau, M. (2005) Panel LM unit root tests with level shifts. Oxford Bulletin of Economics and Statistics, 67, 393-419.

Leybourne, S. (1995) Testing for unit roots using forward and reverse Dickey-Fuller regressions. Oxford Bulletin of Economics and Statistics 57, 559-571.

Li, J. (2006) Testing Granger Causality in the Presence of Threshold Effects. International Journal of Forecasting 22, 771-780.

Luukkonen, R., P. Saikkonen, and T. Terasvirta (1988) Testing Linearity against Smooth Transition Autoregressive Models. Biometrika 75, 491-499.

Masih, A.M.M., Masih, R., 1998. A multivariate cointegrated modeling approach in testing temporal causality between energy consumption, real income and prices with an application to two Asian LDCs. Applied Economics 30 (10), 1287-1298.

Omay, T. and E.O. Kan (2010) Re-examining the Threshold Effects in the InflationGrowth Nexus: OECD Evidence. Economic Modelling 27, 995-1004.

Payne, J.E. (2009) On the dynamics of energy consumption and employment in Illinois, Journal of Regional Analysis and Policy, 39(2): 126-130. 
Pedroni, P. (1999) Critical Values for Cointegration Tests in Heterogeneous Panels with Multiple Regressors. Oxford Bulletin of Economics and Statistics 61, 653-670.

Pedroni, P. (2001) Fully Modified OLS for Heterogeneous Cointegrated Panels. Advances in Econometrics 15, 93-130.

Pesaran, M. (2004) General diagnostic tests for cross section dependence in panels. Cambridge Working Papers in Economics 435, and CESifo Working Paper Series 1229.

Pesaran, M.H. (2007), "A simple panel unit root test in the presence of cross-section dependence", Journal of Econometrics 22, 265-312.

Salim, R. Hassan, Kamrul and Shafiei, S., (2014) Renewable and non-renewable energy consumption and economic growth: Further evidence from OECD countries, Energy Economics, 44: 350-360.

Salim, R., S Rafiq and A. F. M. K. Hassan (2008) Causality and Dynamics of Energy Consumption and Output: Evidence from Non-OECD Asian countries, Journal of Economic Development; 33: 1-26.

Smith, V., Leybourne, S. and Kim, T.-H. (2004) More powerful panel unit root tests with an application to the mean reversion in real exchange rates. Journal of Applied Econometrics 19, 147-170.

Solo, V. (1984) The order of differencing in ARIMA models. Journal of the American Statistical Association 79, 916-921.

Toda, H.Y. and T. Yamamoto. 1995. Statistical infe-rence in vector autoregressions with possibly inte-grated process. Journal of Econometrics 66:225-250.

Tugcu, C.T., Ozturk, I., Aslan, A., 2012. Renewable and non-renewable energy consumption and economic growth relationship revisited: evidence from G7 countries. Energy Economics, 34, 1942-1950.

WEHAB Working Group (2002) A framework for action on energy: World summit on sustainable development. Johannesburg, South Africa.

Westerlund, J. (2006) Testing for panel cointegration with multiple structural breaks. Oxford Bulletin of Economics and Statistics 68, 101-132.

Westerlund, J. and Edgerton, D.L. (2007) A Panel Bootstrap Cointegration Test, Economics Letters 97, 185-190.

World economic Forum (2012), Energy for Economic growth, Energy Vision Update 2012, Geneva, Switzerland. 